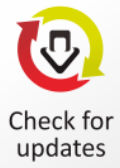

updates

\section{Knowledge Sharing Behaviour: the Effect of Psychological Safety on Balance Scorecard (BSC) Implementation}

\author{
Siti Rodiah ${ }^{1 *}$ and Ertambang Nahartyo ${ }^{2}$
}

\begin{abstract}
This study aims to compare the influence of transformational and transactional leadership on psychological safety. In addition, it examines the effect of psychological safety on the scope of balanced scorecard (BSC) implementation through knowledge sharing behaviour. This study uses a $2 \times 2$ between-subjects experimental design and independent t-test to test Hypotheses 1 and 2 . Hypotheses 3 and 4 use hierarchical regression. To answer the questions in this study, the researchers conducted experiments with Master of Accounting and Master of Economics Development students at the Faculty of Economics and Business, Gadjah Mada University. The results of the hypothesis testing in this study support Hypotheses 1, 2 and 3, while Hypothesis 4 is not supported because it does not meet the requirements of mediation testing.
\end{abstract}

KEYWORDS: leadership style; psychological safety; knowledge sharing behaviour; balanced scorecard (BSC)

\section{Introduction}

A number of companies around the world have achieved successful implementation of the balanced scorecard (BSC), while the same has not always been true for various other companies. This can be attributed to several factors, including the manager's cognitive limitations in processing and understanding the information presented by the scorecards of each business unit, the high cost of technology and employee training (Lipe \& Salterio, 2000) and the excessive information arising from the design of the BSC that leads to managers tending to ignore some of it (Neumann, Roberts, \& Cauvin, 2010). Such limitations and difficulties in the application of the BSC result in general measurement bias (Lipe \& Salterio, 2000). It is possible to reduce this bias by adding BSC knowledge (Dearman \& Shields, 2005; Dilla \& Steinbart, 2005; Jassem, Azmi, \& Zakaria, 2018). However, not all employees in the company will have the same knowledge and understanding of BSC due to their different educational backgrounds (Dearman \& Shields, 2001). As such, differences in understanding of employee accounting have a considerable effect on managerial decision-making.

Knowledge sharing can be use to minimize the differences of knowledge and understanding of BSC. Knowledge sharing behaviour refers to the provision of task information and knowledge for the purpose of assisting and collaborating with others to solve problems, develop new ideas or implement policies or procedures (Wang \& Noe, 2010). In addition, knowledge sharing behaviour is evident when looking at how to increase the effectiveness of BSC implementation (Lin, 2015; Malina \& Selto, 2001).

Various firms, however, have failed in their attempts to apply knowledge 
sharing behaviour among employees, accounting for an annual total of approximately $\$ 31.5$ billion in lost revenues behaviour (Babcock, 2004). This failure behaviouris caused by a lack of consideration of the organisational and interpersonal context and individual characteristics in influencing knowledge sharing behaviour (Carter \& Scarbrough, 2001; Voelpel, Dous, \& Davenport, 2005).

Kessel, Kratzer, and Schultz (2012) examined the effect of psychological safety on knowledge sharing behaviours that can drive the performance of the creative team. Their study employed a questionnaire that was sent to 73 health teams focused on rare diseases. The results of the study demonstrated that high psychological safety in the creative team is able to improve performance through knowledge sharing. Siemsen, Roth, Balasubramanian, and Anand (2009) examined the effect of psychological safety on knowledge sharing behaviour among co-workers in service and manufacturing firms. They sent questionnaires to four different companies and discovered psychological safety to be an important factor in improving knowledge sharing behaviour. Choo, Linderman, Schroeder, Linderman, and Schroeder (2007) examined the influence of knowledge creation and learning behaviours in mediating the relationship between psychological safety and performance. Employing Edmondson's psychological safety questionnaire (1995), their study found that psychological safety significantly influences the creation of knowledge but not learning behaviour. As a result, there is an empirical gap in the psychological safety effect on knowledge sharing behaviour.

Several prior studies have proven that psychological safety can improve knowledge sharing behaviour among employees. However, there has been little research identifying leadership style as a factor that can encourage employee psychological safety (Cannon \& Edmondson, 2001; Nembhard \& Edmondson, 2006; Ortega, Van den Bossche, Sánchez-Manzanares, Rico, \& Gil, 2014). Peng, Lin, Schaubroeck, McDonough, and Zhang (2016) conducted a study comprising a survey of 43 employees at an industry innovation firm. They found that low employee performance when faced with a intellectually stimulating property will have meaningfulness in the workplace.

In addition, it was found that leaders with styles of leadership based on intellectual stimulation were better at fostering employee motivation than those with styles centred on inspirational motivation, individual attention and individual influences. This is in contrast to Quintana, Park, and Cabrera (2015), who found that an individual influence style of leadership exerted a greater influence on employee job satisfaction.

Similarly, with regard to the transactional leadership style of contingent rewards, Podsakoff, Podsakoff, and Kuskova (2010) reviewed a number of earlier studies into misconceptions related to the application of transactional leadership styles of contingent rewards and active management by exception (MBE). They discovered that the transactional leadership style of contingent rewards was better at influencing employee behaviour compared to an active MBE transactional leadership style. 
The current study develops the research of Malina and Selto (2001) and Lin (2015). Malina and Selto (2001) examined the effectiveness of the BSC through communication and control systems by conducting interviews with its designers, Administration and North American divisional managers. The results of the interviews demonstrated that BSC is an effective tool for controlling corporate strategy. In addition, their study found that conflict and poor motivation among management over the use of the BSC as an evaluation tool was caused by ineffective communication and management control.

Lin (2015), in contrast, examine the influence of knowledge sharing on the effectiveness of the BSC (learning and growth, internal processes, customer satisfaction and financial performance) by sending questionnaires to 244 managers responsible for $\mathrm{KM}$ projects in their company. The results identified knowledge sharing as the strongest predictor of internal process performance. In addition, the study indicated that non-financial performance measures (i.e. learning and growth, internal processes and customer satisfaction) directly and indirectly affect financial performance through causal relationships.

In our current research, we seek to examine the effect of transactional and transformational leadership on psychological safety, which has been alleged to increase knowledge sharing behaviour. In addition, this study uses experimental methods in testing the effect of transactional and transformational leadership styles on employee psychological safety. The researchers use experiments for the reason that the experimental method is considered to be the most appropriate method for testing the impact of cause and effect. Compared with other methods, the experimental method promises better results that are high-confidence with regard to the existence of causal relationships between independent and dependent variables (Nahartyo \& Utami, 2016).

We make a contribution through this research theoretically by seeking to provide empirical evidence that leadership style, in terms of both transformational and transactional styles, can create good psychological safety conditions and will ultimately improve employee performance. Practically, this study provides an overview of the importance of improving the psychological safety of employees at work and of building knowledge sharing behaviourbehaviour together based on full awareness and high discipline so that the implementation of knowledge sharing behaviour can increase the scope of BSC implementation in each business unit of the company.

\section{Literature Review and Hypotheses Development}

\section{The Balanced Scorecard and its Scope of Implementation}

The BSC is a set of measurements consisting of financial, customer satisfaction, internal business processes and learning and growth that assist top management in providing a rapid and comprehensive view of the company (Kaplan \& Norton, 1996). The BSC is also used as a tool for 
translating strategic goals and communicating at all levels within the organisation, introducing initiatives to achieve goals and evaluating whether targets have been achieved (Niven, 2010).

Kaplan and Norton (1992) explain that within the BSC's four perspectives from which to view the organisation, there are usually 16-28 different sizes grouped into 4-6 categories, including non-financial (cycle time, customer satisfaction) and financial measurements (sales growth, debt ratio). In addition, all business units within a company are required to have their own scorecards that reflect their own strategies (Kaplan \& Norton, 1993).

Since its introduction by Kaplan and Norton (1992), the BSC has been widely used by managers in organisations. Approximately 60 per cent of large U.S. companies and 53 per cent of companies worldwide use the BSC, thus making it one of the six most widely used management tools globally, with managers rating it highly in terms of satisfaction. The BSC has also been incorporated into management accounting teaching and has become a service offered by professional management accounting bodies and many management consulting firms (Cooper, Ezzamel, \& Qu, 2017).

Lipe and Salterio (2000), however, present conflicting evidence, showing instead that some companies fail to properly apply the BSC due to its complexity and associated expensive technology and employee training. Kaufmann and Becker (2013) conducted a qualitative study investigating factors that thwarted the application of the BSC, identifying several inhibitors to its application, commencing at the initiation and set-up stages and also at the stage of the BSC itself.

\section{Psychological Safety and Knowledge Sharing Behaviour}

Psychological safety refers to an individual's belief that he is capable of showing and engaging himself in a job without fear of any negative consequences that will affect his self-image, status or career (Kahn, 1990). Psychological safety also encourages a climate characterised by interpersonal trust and mutual respect among team members (Edmonson, 1999). Psychological safety in an organisation can be created in various ways, including through interpersonal relationships, group dynamics and intergroup relationships, process and management style, and organisational norms (Kahn, 1990).

Based on the definitions of psychological safety put forward by Kahn (1990) and Edmondson (1999), it can be concluded that psychological safety can encourage someone to share their knowledge and problems with others without any fear or anxiety over the risks they may face. Knowledge sharing is itself a process in which individuals exchange their knowledge (explicit and tacit) and together create new knowledge (van den Hooff \& de Ridder, 2004). Explicit knowledge is knowledge that is codified and articulated in words, figures and numbers. It is an objective type of knowledge that is relatively easy to share in the form of specifications, standard operating procedures and data. Tacit knowledge, meanwhile, is knowledge that has not been codified and is relatively difficult to codify. This type of knowledge is subjective and based on individual experience (Anand, Oriani, \& Vassolo, 2010). 


\section{Hypotheses Development}

Based on the organisational research literature, Schein and Bennis (1965) stated that psychological safety can create a sense of safety and change individual behaviour towards shifting organisational challenges. Bass, Avolio, Jung, and Berson (2003) suggested that psychological safety can be built within a company through the intellectual stimulation dimension of leadership. Leadership of this type builds psychological safety within the company by increasing the attention and awareness of subordinates to the problems at hand, in turn promoting their ability and tendency to consider and deal with problems in new ways (Rafferty \& Griffin, 2004). In addition, intellectual stimulation leadership will help subordinates who are in trouble by providing a range of alternatives from which to choose. This indicates the support and challenges provided by superiors in improving the ability of subordinates to solve problems (Scholl, 1999).

Zhou, Hirst, and Shipton (2011), in their study, showed that subordinates who had the opportunity to participate in a promotional activity tended to experience frustration and a lack of enthusiasm when there was little or no support in the form of intellectual stimulation leadership. Furthermore, while subordinate participation is capable of generating opportunities for subordinates to voice their creative ideas in a focused way, they will nevertheless experience mental or intellectual stimulation from their superiors.

The results obtained by Zhou et al. (2011), as mentioned above, are consistent with those of Peng et al. (2016). They suggested that the intellectual stimulation dimension of transformational leadership, in comparison to the other dimensions (i.e. inspirational motivation, individual influence, individual attention), focuses more on the task of motivating and directing subordinates to alter the way they think about their roles and occupations within the company.

$H_{1}$ : Individuals faced with employers who stimulate employees will have higher psychological safety than individuals who are faced with a boss who motivates employees.

Bass et al. (2003) found transactional leadership with contingent rewards to be more effective in setting clear expectations and goals for subordinates so as to motivate them towards goal achievement, in contrast to transactional leadership with active MBE that hands out punishment to subordinates. In addition, contingency rewards were found to positively influence the attitudes and behaviours of subordinates (Bass et al., 2003; Walumbwa, Wu, \& Orwa, 2008). This arises since the behaviour of leaders who emphasise contingent rewards and reinforce the importance of meeting performance expectations can create a common norm that promotes efficient, systematic and organised organisational behaviour (Quintana et al., 2015).

In addition, Podsakoff et al. (2010) found some evidence of the benefits of providing contingent rewards to employees, including a reduction in the degree of cynicism felt by employees and an increase in employees' trust in organisational change. Furthermore, Podsakoff et al. (2010) stated that 
negative feedback obtained from punishment can have an adverse effect on the emotions and attitudes of employees. However, the punishments handed out will be more effective if accompanied by an explanation by the supervisor of the mistakes made by the subordinates. Based on the findings of Quintana et al. (2015) and Podsakoff et al. (2010), the next hypothesis in this study can be formulated as follows:

$\mathrm{H}_{2}$ : Individuals who are faced with superiors who like to give rewards to subordinates will have higher psychological safety than individuals faced with superiors who like to give punishment to subordinates.

BSC is a management strategy tool that provides feedback on internal business processes and external outcomes that can improve organisational performance (Lin, 2015). The BSC looks at the organisation from four perspectives (financial, customer satisfaction, internal business processes and learning and growth) and has been widely adopted or implemented by companies across the world. However, a number of issues have been identified in the process; for example, the cognitive limitations of individuals with regard to processing and understanding the large volume of information generated by the BSC (Lipe \& Salterio, 2000; Neumann et al., 2010), thereby giving rise to a tendency on the part of management to ignore some of the BSC information. This leads to a general measurement bias that in turn reduces the potential benefits of BSC as a unique measurement tool that can be of great value in capturing the business unit strategy; in other words, the company is unable to reap the benefits of implementing BSC. A failure to adequately implement BSC will have a negative impact on the company due to the significant amount of effort expended in terms of both energy and cost (Lipe \& Salterio, 2000).

When employees make a mistake and/or fail in a job, they tend not to tell their co-workers and supervisor out of a concern that, if disclosed, it would result in damage to their self-image and may even be considered as incompetence by colleagues. Schein and Bennis (1965) revealed that such a fear of loss of self-image and punishment for disclosure of errors can be overcome by creating a condition of psychological safety. Psychological safety provides support and a comfortable climate so that individuals can engage in thought and innovation (Carmeli \& Gittell, 2009).

Based on the theory of cooperation (Deutsch, 1973), psychological safety can be realised in an organisation if there are shared goals. Individuals or groups with the same goals will be able to express their feelings and doubts to help each other and combine ideas in order to develop more effective methods in the future (Chen \& Tjosvold, 2012). Adoption of the BSC should lead to an alignment of objectives and strategies between the business unit and the wider organisation (Lipe \& Salterio, 2000) so that all employees in the company are able to help and provide support for the effective and efficient implementation of the BSC (Niven, 2010). Several previous studies have found that psychological safety positively affects employee creativity in relation to performance outcomes (Edmonson, 1999; Kessel et al., 2012), performance results (Edmondson, 1999), the adoption and implementation of innovation in large groups or organisations (Baer \& Frese, 2003) and company performance (Choo et al., 2007). Based on the theory of 
collaboration and the findings from Kessel et al. (2012), Choo et al. (2007) and Edmondson (1999), the researchers formulated the following hypothesis:

$H_{3}$ : Psychological safety positively affects the scope of BSC implementation.

Dilla and Steinbart (2005) examined the role of BSC knowledge on general measurement bias, with the results of their study indicating that managers have knowledge of BSC in relation to the use of general measurements, but that unique measurements are often overlooked (only a small proportion of the measurements are used a little). Likewise, Dearman and Shield (2005) found that individuals with knowledge relevant to their duties will be able to produce more appropriate decisions. Based on these two studies, it can be concluded that knowledge is very important in implementing BSC. However, due to the fact that each individual has different knowledge, which means the scope of BSC implementation is not maximal, general measurement bias remains.

The organisational communication literature reveals that effective organisational communication of the BSC consisting of messages that are true (valid), combined with its support for organisational culture and knowledge sharing behaviour, will create a positive alignment of strategy, motivation and organisational outcomes towards the implementation of the BSC. This has been proven by Malina and Selto (2001), who found that effective organisational communication has a beneficial effect on changes in the process and improvement of the BSC and customer-based services. Conversely, ineffective communication will result in a lack of motivation and conflict in the application of the BSC as a performance evaluation tool.

Social exchange theory explains that individual behaviour is strongly influenced by the quality of relationships between individuals and organisations (Blau, 1964). When the quality of the relationship between employees and the organisation is well marked by the emergence of a sense of security towards their psychology, employees tend to make social exchanges compared to economic exchanges ( $\mathrm{Li}, \mathrm{Wu}$, Liu, Kwan, \& Liu, 2014). The quality of good relations between employees and their organisations can also arise due to the similarity of objectives between the two parties.

The quality of relationships and common goals between employees and organisations indicates that the psychological safety felt by employees encourages them to share problems and knowledge with each other ( $\mathrm{Li}$ et al., 2014; Chen \& Tjosvold, 2012; Kessel et al., 2012; Edmonson, 1999; Siemsen et al., 2009; Edmondson, 1999), which in turn will influence both employee involvement in creative work (Gong, Cheung, Wang, \& Huang, 2012) and team performance (Choo et al., 2007; Edmondson, 1999). Based on the theory of cooperation and social exchange theory and the results of research from Chen and Tjosvold (2012) and Kessel et al. (2012), the researchers formulated the following hypothesis:

$\mathrm{H}_{4}$ : Knowledge sharing behaviour mediates the effect of psychological safety on the scope of BSC implementation. 


\section{Research Method}

The research method used in this research is the experimental method. The experiment aims to examine the effect of top management leadership style on the participants' psychological safety condition in sharing their knowledge about BSC, such that with knowledge sharing behaviour, the participants are able to use the full scope of BSC implementation.

\section{Experimental Design}

This study used a $2 \times 2$ between-subjects experimental design to manipulate the participants' psychological safety conditions driven by dimensions of transformational leadership (i.e. intellectual stimulation, inspirational motivation) and transactional leadership (contingency rewards, active MBE), as shown in Table 1.

In the first experiment, the researchers compared the influence of the intellectual stimulation dimension of transformational leadership on psychological safety with that of the inspirational motivation dimension of transformational leadership. For the second experiment, the researchers compared the influence of contingent reward transactional leadership on psychological safety with that of active MBE transactional leadership.

\section{Experimental Procedure}

Prior to the participants starting the experiment, the experimenter distributed a questionnaire for them to complete. The participants were prohibited from opening the questionnaire until the research assistant had provided a brief explanation of the BSC and the procedure for filling in the questionnaire. The experimenter's goal of explaining the BSC was to ensure that the participants properly understood the tasks they were going to perform.

Then, the experimenter asked the participants to open their questionnaires and verify that the number of pages in their copies was the same as in those received by the other participants. During the experiment, the experimenter guided the course of the experiment by directing the participants to open and resolve the cases at the same time.

The questionnaire distributed to the participants comprised two parts. The first part comprised a case asking the participants to act as divisional managers who get their boss's superiors to apply BSC in their division. The BSC implementation begins by incorporating the division's strategy into performance measures based on the four perspectives: financial, customer satisfaction, internal business processes and learning and growth. The following page contained two questions in the form of manipulation checks,

Table 1 Experiment Design

\begin{tabular}{clcc} 
& & \multicolumn{2}{c}{ Transactional Leadership } \\
& & Contigency reward & MBE-Active \\
\hline $\begin{array}{c}\text { Transformational } \\
\text { Leadership }\end{array}$ & Intelectual Stimulation & Cell 1 & Cell 2 \\
\hline
\end{tabular}


designed to ensure that all of the participants were aware of the cases and roles that had been assigned to them.

The participants were then instructed to look at the next page which contained a number of questions to be answered in accordance with how they felt. Finally, the participants completed the demographic data which marked the end of the experimental process.

\section{Pilot Test, Check of Understanding and Manipulation}

In order to verify that the expected understanding could be achieved, a pilot test was conducted among 30 students on the Master of Accounting degree programme at Gadjah Mada University's (UGM) Faculty of Economics and Business that were not included in the research sample. A pilot test is conducted with the aim of determining whether or not the given case can be understood by the participants. Evaluation of the pilot test results can take the form of improvements so that the perceptions given and language used can be more easily understood by the participants. The participants in the pilot test are not able to then be experimental participants. With the aim of improving quality, the experimental material was equipped with manipulation and understanding items. Following the experimentation, the manipulation check was performed first. Of the participants who passed the manipulation check, those who answered incompletely were recapitulated in the experiment implementation report. Thus, those participants who passed both the manipulation check and the demographic completeness and completeness of the experimental fields would be further processed.

\section{Participants}

The participants in this study were students on the Master of Accounting and Master of Economics Development programmes of the Faculty of Economics and Business at UGM, with a total of 84 people meeting the study criteria of having received management accounting courses (management control system) through its classes, or otherwise having worked. The reason for the selection of students as the sample of this study was because students are appropriate representatives or substitutes to replace the role of the manager in decision-making and consideration research (Clinton, 1999, in Cheng, Axel, \& Luckett, 2003). In addition, the researcher assumed that students from both courses would be accustomed to examining cases about the business world in their lectures. The pilot test in this research comprised 30 students from the Master Program of Accounting Science at the Faculty of Economics and Business, UGM and who were not included in the research sample.

\section{Definition and Operationalisation of Variables}

Psychological safety is defined as the belief held by an individual that he is able to speak in a group without any feeling of shame, rejection from others or other negative consequences that may reduce his self-image or status (Kahn, 1990). Psychological safety is measured using a questionnaire consisting of three statements, with each statement representing the 
individual's feeling with regard to voicing difficulties. The questionnaire was adapted from Siemsen et al. (2009).

van den Hooff and de Ridder (2004) defined knowledge sharing behaviour as a process in which individuals exchange their (explicit and tacit) knowledge and together create new knowledge. The variable is measured using questionnaires adopted from van den Hooff and Ridder (2004) consisting of ten statements, with each statement rated on a 1-5 Likert scale as follows: 1 = strongly disagree; 2 = disagree; 3 = neutral; 4 = agree; and 5 = strongly agree.

The assumption of the scope of BSC implementation is that the manager uses the full scope of the BSC for both general size and unique size in a balanced way. In a situation where a manager has greater knowledge of parts of the BSC than their teammates and colleagues, and the manager is not reluctant to share this knowledge, this is expected to facilitate the effective use of the BSC by all of the managers of each division.

To gauge whether the participants have used all of the BSC measures, the researchers scored each perspective in terms of performance measures. The scoring undertaken on performance measures is based on the degree of conformity between the strategy and the performance measures used in the BSC. The researchers provided a sequence of numbers in each BSC perspective on the task table, in addition to the order of magnitude of the performance measures in each perspective. The most unique performance aspects were awarded a score of 4 , with the most common scored 1 . The range of possible scores that the participants could attain was from 4 to 16 .

\section{Hypothesis Testing Technique}

Hypotheses 1 and 2 were tested using the independent sample t-test by comparing the total mean value of the $A \& B$ cells with the total mean value of the $C \& D$ cells. Hypothesis 1 is supported if the total mean of the $A \& B$ cells is greater than that of the total mean for cells $C \& D$. Hypothesis 2 was tested by comparing the total value of the mean of the $A \& C$ cells to the total mean value of the $B \& D$ cells. Hypothesis 2 is supported if the mean total value of the $A \& C$ cells exceeds the total mean for the $B$ \& D cells.

The testing for Hypotheses 3 and 4 in this study consisted of hierarchical regression analysis developed by Baron and Kenny (1986). Their concept was chosen because it contains detailed statistical steps and criteria that distinguish the mediating influence in the following three groups: fully mediated, partially mediated and having no mediation effect at all. A variable can be said to function as a mediating variable if it satisfies the following conditions (Baron \& Kenny, 1986):

1) The variances of the independent variables significantly influence the mediating variable (part a)

2) The variance of the mediating variable has a significant effect on the variance of the dependent variable (part b)

3) When the first relationship (part a) and the second relationship (part b) are controlled, the relationship between the independent variables and the dependent variable (part c) is initially significant to be insignificant or 
Table 2 Independent Sample t-test of Hypothesis 1

\begin{tabular}{|c|c|c|c|c|c|}
\hline & \multicolumn{2}{|c|}{$\begin{array}{l}\text { Levene's test for } \\
\text { equality of variances }\end{array}$} & \multirow[t]{2}{*}{ Mean } & \multirow[t]{2}{*}{ t-statistic } & \multirow[t]{2}{*}{ Sig. } \\
\hline & $\mathrm{F}$ & Sig. & & & \\
\hline Intellectual stimulation & \multirow{2}{*}{0.981} & \multirow{2}{*}{0.329} & 12.94 & \multirow{2}{*}{5.372} & \multirow{2}{*}{0.000} \\
\hline Inspiration motivation & & & 10.74 & & \\
\hline
\end{tabular}

the relationship of perfect mediation or the significance of the value of the independent variable down (partial mediation).

\section{Result and Discussion}

Based on the results of an examination of the answers given by the 84 participants who took part in the experiment, 2 participants (2\%) did not pass the manipulation check, and 10 participants (12\%) failed to completely fill in the demographic data. As a result, the answers given by 72 participants $(86 \%)$ can be used in this research.

The results of the independent sample t-test show that the total mean value of the A \& B cells was 12.94 and the total value of the mean of the $C \& D$ cells was 10.74 . From these results, it can be temporarily concluded that there are differences in the psychological safety conditions of business unit managers between the intellectual stimulation and inspirational motivation dimensions of transformational leadership (12.94 > 10.74). Furthermore, the result of the F arithmetic Levene t-test is 0.981 with significance at 0.329 . Given that the significance is above $0.05(0.329>0.05)$, it can be concluded that both groups have the same variance (i.e. they are homogeneous). The value of $t$ with equal variances assumed is 5.372 , with a significance of 0.000 . Thus, it can be considered that there are differences in the psychological safety conditions of business unit managers between the intellectual stimulation and inspirational motivation dimensions of transformational leadership. Thus, managers faced with superiors that stimulate their employees will have higher psychological safety. Based on the evaluation results above, it can be stated that the hypothesis $(\mathrm{H} 1)$ proposed in this research is supported.

Furthermore, the second hypothesis testing shows that the mean total value of the A \& B cells is 8.35 , while the total mean value of the $C \& D$ cells is 6.06. From these results, it can be temporarily concluded that there are differences in the psychological safety conditions of business unit managers between transactional leadership of contingent rewards and active MBE

Table 3 Independent Sample t-test of Hypothesis 2

\begin{tabular}{lcccccc}
\hline & \multicolumn{2}{c}{$\begin{array}{l}\text { Levene's test for } \\
\text { equality of variances }\end{array}$} & Mean & t-statistic & Sig. \\
& F & Sig. & & & \\
\hline $\begin{array}{l}\text { Contingency rewards } \\
\text { MBE-Active }\end{array}$ & 0.222 & 0.641 & $\begin{array}{l}8.35 \\
6.06\end{array}$ & 3.493 & 0.001 \\
\hline
\end{tabular}


Table 4 Results of Direct Effect Hypothesis Test

\begin{tabular}{lcccccc}
\hline \multirow{2}{*}{ Independent Variable } & \multicolumn{6}{c}{ Dependent Variable : Scope of BSC Implementation } \\
& $\boldsymbol{B}$ & $\mathrm{t}$ & $\mathrm{Sig}$. & $\mathrm{R}^{2}$ & Adjust. $^{2}$ & $\mathrm{~F}$ \\
\hline Psychological Safety & 0.441 & 3.920 & 0.000 & 0.259 & 0.177 & 0.006 \\
\hline
\end{tabular}

$(8.35$ > 6.06). Furthermore, the $\mathrm{F}$ arithmetic Levene t-test result is 0.222 with significance at 0.641 . Given that the significance is greater than 0.05 $(0.641>0.05)$, it can be concluded that both groups have the same variance (i.e. they are homogeneous). The value of $t$ with equal variances assumed is 3.493 , with a significance of 0.001 . Thus, it can be considered that there are differences in the psychological safety conditions of business unit managers between transactional leadership of contingent rewards and active MBE. Thus, managers faced with rewarding bosses will have higher psychological safety. Based on the results of the above evaluation, it can be stated that the hypothesis $(\mathrm{H} 2)$ proposed in this study is supported.

\section{Direct Effect Testing}

Hypotheses 3 and 4 in this study were tested using hierarchical regression analysis with the help of SPSS 21.0. From the hypothesis test result, the psychological safety variable had a positive effect on the scope of BSC implementation ( $\beta=0.441 ; \mathrm{t}=3.920$; sig $=0.000$ ).

\section{Indirect Effect Testing}

The next hypothesis was tested to determine whether the knowledge sharing behavioural variable mediates the psychological safety effect on the scope of BSC implementation. The first stage of testing indicated that psychological safety is not significant to knowledge sharing behaviour $(B=-$ $0.142 ; \mathrm{t}=-1.233$; sig $=0.222$ ). In the second phase of testing, the psychological safety variable was found to have a positive and significant effect on the scope of BSC application ( $\beta=0.441 ; t=3.920$; sig = 0.000). In the third stage of testing, the effect of knowledge sharing behaviour on the scope of BSC application changed to insignificant $(\beta=-0.023 ; \mathrm{t}=-0.184 ; \mathrm{sig}=$ $0.855)$.

Based on the result of the independent t-test, Hypotheses 1 and 2 are supported. The results obtained for Hypothesis 1 are consistent with Zhou et al. (2011) and Peng et al. (2016). This indicates that individuals confronted

Table 5 Hypothesis Test Results with Mediation Variables

\begin{tabular}{|c|c|c|c|c|c|c|c|c|c|}
\hline \multirow{3}{*}{$\begin{array}{l}\text { Independent } \\
\text { Variable }\end{array}$} & \multicolumn{3}{|c|}{ Step 1} & \multicolumn{3}{|c|}{ Step 2} & \multicolumn{3}{|c|}{ Step 3} \\
\hline & \multicolumn{3}{|c|}{$\begin{array}{c}\text { Knowledge Sharing } \\
\text { Behavior }\end{array}$} & \multicolumn{3}{|c|}{$\begin{array}{c}\text { Scope of BSC } \\
\text { Implementation }\end{array}$} & \multicolumn{3}{|c|}{$\begin{array}{c}\text { Scope of BSC } \\
\text { Implementation }\end{array}$} \\
\hline & $\beta$ & $\mathrm{t}$ & Sig. & $\beta$ & $\mathrm{t}$ & Sig. & $\beta$ & $\mathrm{t}$ & Sig. \\
\hline Psychological Safety & -0.142 & -1.233 & 0.222 & 0.441 & 3.920 & 0.000 & 0.438 & 3.817 & 0.000 \\
\hline $\begin{array}{l}\text { Knowledge Sharing } \\
\text { Behavior }\end{array}$ & & & & & & & -0.023 & -0.184 & 0.855 \\
\hline$R^{2}$ & & & 0.225 & & & 0.259 & & & 0.259 \\
\hline Adjust $R^{2}$ & & & 0.140 & & & 0.177 & & & 0.165 \\
\hline $\mathrm{F}$ & & & 0.018 & & & 0.006 & & & 0.011 \\
\hline
\end{tabular}


with employers who stimulate employees will have higher psychological safety because intellectual stimulation leadership compared to the other dimensions of transformational leadership (inspirational motivation, individual influence, individual attention) focuses more on the task of motivating and directing subordinates to change the way they think about their roles and occupations within the company. Furthermore, the results for Hypothesis 2 are consistent with Quintana et al. (2015) and Podsakoff et al. (2010). Individuals faced with superiors who like to give rewards to subordinates will have psychological safety since this can reduce the degree of cynicism felt by employees and increase the employees' trust in organisational change.

Based on the result of the regression analysis, Hypothesis 3 that psychological safety has a positive and significant effect on the scope of BSC application, is supported. The results of this study are consistent with Cannon and Edmondson (2001) in that individuals with good psychological safety conditions will feel that their ability and personality are respected, believe they are free to ask for help and take risks, have little fear of blame and believe that other people will not seek to undermine their efforts. This indicates that managers who are having difficulty in implementing BSC in their business units will not live in fear of the bad opinions and punishment from their business associates and bosses if they express the difficulties they have experienced. In addition, it can also be an encouragement for managers because those people around them will not be seeking to curtail their efforts in finding an alternative solution to implement BSC.

Based on the results of the hierarchical regression analysis, Hypothesis 4 that has been proposed by researchers to obtain data or results that can not support knowledge sharing behaviour that mediate the influence of psychological safety to the scope of application of BSC. These results are inconsistent with those obtained by Kessel et al. (2012). This indicates that the psychological safety effect derived from knowledge sharing behaviour is not necessary to improve the scope of BSC implementation. Psychological safety can directly affect the scope of BSC implementation by not permitting the blaming and awarding of sanctions to managers, such that they can freely improve all efforts to achieve their objectives.

Unsupported knowledge sharing behaviour as a mediating variable in the psychological safety effect can also be generated by a number of factors, including the existence of competition between members both within and outside the teams where employees work. According to competition theory (Deutsch, 1973), each individual has a different purpose in doing a job so that they voluntarily make small sacrifices for other individuals. They assume that revealing the problems and difficulties they encounter will provide new knowledge for other individuals which can be used to hinder their efforts in achieving goals. Similarly, within the scope of BSC implementation, it may be that business unit managers have different objectives, thus hindering them from sharing knowledge and resulting in the scope of BSC implementation.

Another factor is the level of busyness or work pressure faced by other individuals. Based on adaptive cost theory (Cohen, 1978), individuals faced with multiple tasks tend to focus on their own problems and are less sensitive to the needs of other individuals. So when managers seek to 
express the difficulties they face, their colleagues or bosses may have similar difficulties or pressures in the job that result in them ignoring the manager (Ford, Myrden, \& Jones, 2015).

In addition, the failure of knowledge sharing behaviour can be attributed to the different cognitive abilities of individuals, whereby some individuals may have difficulties in digesting new knowledge that has been communicated by their peers or superiors; as such, the intensity of knowledge sharing behaviour will become less effectivebehaviour in terms of affecting the scope of BSC implementation. Hunter and Hunter (1984), in (Bell \& Kozlowski, 2002), suggest that cognitive ability is a major predictor to consider when examining the effect of learning with outcomes, especially in relation to complex tasks.

\section{Conclusion}

This study has compared the effect of the intellectual stimulation and inspirational motivation dimensions of transformational leadership on psychological safety. The study has also sought to compare the effect of contingent reward transactional leadership with that of active MBE on psychological safety. Furthermore, this study examined the effect of psychological safety on the scope of BSC implementation. It also looked at the role of knowledge sharing behaviour as a mediating variable on the influence of psychological safety on the scope of BSC implementation. Based on the results of statistical tests, it was found that the psychological safety of employees can be built into a company that implements the transformational leadership styles of intellectual stimulation and contingent reward. Furthermore, individual behaviour in achieving goals can change based on the reciprocal patterns of interaction between behaviour, personal and environmental. An environment that communicates a bad signal can change a person's behaviour. Ultimately, knowledge sharing behaviour is capable of increasing the scope of BSC implementation if managed properly by the individuals involved.

Theoretically, the results of this study are able to provide empirical evidence that both transformational and transactional leadership styles can create good psychological security conditions and will ultimately improve employee performance. Furthermore, practically, this study provides an overview of the importance of improving the psychological safety of employees in the workplace and building knowledge sharing together, accompanied by full awareness and high discipline so that the application of knowledge sharing behaviour can increase the scope of BSC implementation in each business unit of the company.

This study also has limitations; first, the experiment in this study tested only the main effect, or, in other words, it only carried out a comparison between cells $A$ and $B$ and cells $C$ and $D$, with no interaction test. Future research may thus wish to use interaction effects testing by undertaking the following comparisons: intellectual stimulation dimension of transformational leadership/transactional leadership style of contingent reward with the inspirational motivation dimension of transformational leadership / active 
MBE transactional leadership style (Quintana, 2015). Second, the experimental design proved to be somewhat confusing for the participants, which, coupled with some fairly large questionnaire statements, led to the participants being somewhat biased in answering them. Third, all of the participants in this study had attended a control system course, although some had not received material on BSC. Future research may thus seek to use participants who have studied BSC equally in order to avoid bias in the examination of the given cases.

In addition, further research might employ organisation culture variables that can encourage employee knowledge sharing behaviour so as to increase the scope of BSC implementation and, finally, future research may look to incorporate an environmental perspective into the scope of BSC application as new knowledge held by managers that can be shared with other partners in the company.

\section{References}

Anand, J., Oriani, R., \& Vassolo, R. S. (2010). Alliance Activity as a Dynamic Capability in the Face of a Discontinuous Technological Change. Organization Science, 21(6), 1213-1232. https://doi.org/10.1287/orsc.1090.0502

Babcock, P. (2004). Shedding Light on Knowledge Management.

Baer, M., \& Frese, M. (2003). Innovation is not enough: Climates for initiatives and psychological safety, process innovations, and firm performance. Journal of Organizational Behavior, 24(May 2002), 45-68.

Baron, R. M., \& Kenny, D. a. (1986). The Moderator-Mediator Variable Distinction in Social The Moderator-Mediator Variable Distinction in Social Psychological Research: Conceptual, Strategic, and Statistical Considerations. Journal of Personality and Social Psychology, 51(6), 1173-1182. https://doi.org/10.1037/0022-3514.51.6.1173

Bass, B. M., Avolio, B. J., Jung, D. I., \& Berson, Y. (2003). Predicting unit performance by assessing transformational and transactional leadership. Journal of Applied Psychology, 88(2), 207-218. https://doi.org/10.1037/0021-9010.88.2.207

Bell, B. S., \& Kozlowski, S. W. J. (2002). Goal orientation and ability: Interactive effects on self-efficacy, performance, and knowledge. The Journal of Applied Psychology, 87(3), 497-505. https://doi.org/10.1037/0021-9010.87.3.497

Cannon, M. D., \& Edmondson, A. C. (2001). Confronting failure:Antecedents and consequences of shared beliefs about failure in organisational work groups. Journal of Organisational Behaviour, 22(161-177), 161-177. Retrieved from http:// ezproxy.snhu.edu/login?url=http://search.ebscohost.com/login. aspx?direct $=$ true $\& \mathrm{db}=\mathrm{bth} \& \mathrm{AN}=5524978 \&$ site $=$ eds-live\&scope $=$ site

Carmeli, A., \& Gittell, J. H. (2009). High-quality relationships, psychological safety, and learning from failures in work organizations. Journal of Organizational Behavior, 17(2), 1-20. https://doi.org/10.1002/job

Carter, C., \& Scarbrough, H. (2001). Towards a second generation of KM? The people management challenge. Education and Training, 43(4/5), 9.

Chen, G., \& Tjosvold, D. (2012). Shared rewards and goal interdependence for psychological safety among departments in China. Asia Pacific Journal of Management, 29(2), 433-452. https://doi.org/10.1007/s10490-0109201-0 
Cheng, M. M., Schulz, A. K., Luccket, P. F., \& Booth, P. (2003). The Effects of Hurdle Rates on the Level of Escalation of Commitment in Capital Budgeting. Behavioral Research in Accounting, 15, 63-85.

Choo, A. S., Linderman, K. W., Schroeder, R. G., Linderman, K. W., \& Schroeder, R. G. (2007). and Knowledge Creation in Quality Improvement Projects Method and Psychological Effects on Learning Behaviors and Knowledge Creation in Quality Improvement Projects, (July 2014). https://doi.org/10.1287/mnsc.1060.0635

Cooper, D. J., Ezzamel, M., \& Qu, S. Q. (2017). Popularizing a Management Accounting Idea: The Case of the Balanced Scorecard. Contemporary Accounting Research, 34(2), 991-1025. https://doi.org/10.1111/1911$\underline{3846.12299}$

Dearman, D. T., \& Shields, M. D. (2001). Cost Knowledge and Cost-Based Judgment Performance. Journal of Management Accounting Research, 13(1), 1-18. https://doi.org/10.2308/jmar.2001.13.1.1

Dearman, D. T., \& Shields, M. D. (2005). Avoiding accounting fixation: Determinants of cognitive adaptation to differences in accounting method. Contemporary Accounting Research, 22(2), 351-384. https://doi.org/10.1506/RQ40-UR50-5CRL-YU8A

Dilla, W. N., \& Steinbart, P. J. (2005). Relative Weighting of Common and Unique Balanced Scorecard Measures by Knowledgeable Decision Makers. Behavioral Research in Accounting, 17(1), 43-53. https://doi.org/10.2308/bria.2005.17.1.43

Edmonson, A. C. (1999). Psychological safety and learning behavior in work teams. Administative Science Quarterly, 44(2), 350-383.

Ford, D., Myrden, S. E., \& Jones, T. D. (2015). Understanding “disengagement from knowledge sharing": engagement theory versus adaptive cost theory. Journal of Knowledge Management, 19(3). https://doi.org/10.1108/MBE-09-2016-0047

Gong, Y., Cheung, S. Y., Wang, M., \& Huang, J. C. (2012). Unfolding the Proactive Process for Creativity: Integration of the Employee Proactivity, Information Exchange, and Psychological Safety Perspectives. Journal of Management, 38(5), 1611-1633. https://doi.org/10.1177/0149206310380250

Jassem, S., Azmi, A., \& Zakaria, Z. (2018). Impact of sustainability balanced scorecard types on environmental investment decision-making. Sustainability (Switzerland), 10(2). https://doi.org/10.3390/su10020541

Kahn, W. A. (1990). Psychological Conditions of Personal Engagement and Disengagement At Work. Academy of Management Journal, 33(4), 692724. https://doi.org/10.2307/256287

Kaplan, R. S., \& Norton, D. P. (1993). Putting the Balanced Scorecard To Work. Harvard Business Review, 71(5), 134-142. https://doi.org/10.1177/1056492604268208

Kaplan, R. S., \& Norton, D. P. (1996). Linking the Balanced Scorecard to Strategy. California Management Review, 39(1), 53-79. https://doi.org/10.2307/41165876

Kaufmann, L., \& Becker, A. (2013). Overcoming the Barriers During Implementation and Use of the Balanced Scorecard by Multinational Companies in Brazil Overcoming the Barriers During Implementation and Use of the Balanced Scorecard by Multinational Companies in Brazil, (October), 37-41. https://doi.org/10.1300/J140v06n03

Kessel, M., Kratzer, J., \& Schultz, C. (2012). Psychological Safety, Knowledge Sharing, and Creative Performance in Healthcare Teams. Creativity and Innovation Management, 21(2), 147-157. https://doi.org/10.1111/j.1467-8691.2012.00635.x

Li, J., Wu, L. Z., Liu, D., Kwan, H. K., \& Liu, J. (2014). Insiders maintain voice: A psychological safety model of organizational politics. Asia Pacific 
Journal of Management, 31(3), 853-874.

https://doi.org/10.1007/s10490-013-9371-7

Lin, H. F. (2015). Linking knowledge management orientation to balanced scorecard outcomes. Journal of Knowledge Management, 19(6), 1224 1249. https://doi.org/10.1108/JKM-04-2015-0132

Lipe, M. G., \& Salterio, S. E. (2000). The Balanced Effects Scorecard : of Common Judgmental and Unique Performance Measures. The Accounting Review, 75(3), 283-298. https://doi.org/10.2308/accr.2000.75.3.283

Malina, M. A., \& Selto, F. H. (2001). Communicating and Controlling Strategy: An Empirical Study of the Effectiveness of the Balanced Scorecard. Journal of Management Accounting Research, 13(1), 47-90. https://doi.org/10.2308/imar.2001.13.1.47

Nembhard, I. M., \& Edmondson, A. C. (2006). Making it safe: The effects of leader inclusiveness and professional status on psychological safety and improvement efforts in health care teams. Journal of Organizational Behavior, 27(7), 941-966. https://doi.org/10.1002/job.413

Neumann, B. R., Roberts, M. L., \& Cauvin, E. (2010). Information search using the balanced scorecard: What matters? Journal of Corporate Accounting \& Finance. https://doi.org/10.1002/jcaf.20581

Niven, P. R. (2010). BALANCED SCORECARD STEP-BY-STEP Maximizing Performance and Maintaining Results. New York. https://doi.org/10.1037/023990

Ortega, A., Van den Bossche, P., Sánchez-Manzanares, M., Rico, R., \& Gil, F. (2014). The Influence of Change-Oriented Leadership and Psychological Safety on Team Learning in Healthcare Teams. Journal of Business and Psychology, 29(2), 311-321. https://doi.org/10.1007/s10869-013-9315$\underline{8}$

Peng, A. C., Lin, H. E., Schaubroeck, J., McDonough, E. F., Hu, B., \& Zhang, A. (2016). CEO Intellectual Stimulation and Employee Work Meaningfulness: The Moderating Role of Organizational Context. Group and Organization Management, 41(2), 203-231. https://doi.org/10.1177/1059601115592982

Quintana, T. A., Park, S., \& Cabrera, Y. A. (2015). Assessing the Effects of Leadership Styles on Employees' Outcomes in International Luxury Hotels. Journal of Business Ethics, 129(2), 469-489. https://doi.org/10.1007/s10551-014-2170-3

Rafferty, A. E., \& Griffin, M. A. (2004). Dimensions of transformational leadership: Conceptual and empirical extensions. Leadership Quarterly, 15(3), 329-354. https://doi.org/10.1016/j.leaqua.2004.02.009

Scholl, W. (1999). Restrective Controll and Information pathologies in organization. Journal of Social Issues, 55(1), 101-118.

Siemsen, E., Roth, A. V., Balasubramanian, S., \& Anand, G. (2009). The Influence of Psychological Safety and Confidence in Knowledge on Employee Knowledge Sharing. Manufacturing \& Service Operations Management, 11(3), 429-447. https://doi.org/10.1287/msom.1080.0233

Tjosvold, D. (1998). Employee Involvement in Support of Corporate Values in Successful Organizations : Groups, Cooperative Interaction, and Influence, 35-46.

Voelpel, S. C., Dous, M., \& Davenport, T. H. (2005). Five steps to creating a global knowledge-sharing system: Siemens' ShareNet. Academy of Management Executive, 19(2), 9-23. https://doi.org/10.5465/AME.2005.16962590

Walumbwa, F. O., Wu, C., \& Orwa, B. (2008). Contingent reward transactional leadership, work attitudes, and organizational citizenship behavior: The role of procedural justice climate perceptions and strength. Leadership Quarterly, 19(3), 251-265. https://doi.org/10.1016/i.leaqua.2008.03.004 
Wang, S., \& Noe, R. A. (2010). Knowledge sharing: A review and directions for future research. Human Resource Management Review, 20(2), 115-131. https://doi.org/10.1016/j.hrmr.2009.10.001

Zhou, Q., Hirst, G., \& Shipton, H. (2011). Context matters: Combined influence of participation and intellectual stimulation on the promotion focus-employee creativity relationship. Journal of Organizational Behavior, J. Organiz. Behav. (2011), 17(2), 1-20.

https://doi.org/10.1002/job 